інтеграційний (уміння співпрацювати 3 різними партнерами в групі та команді, виконувати різні ролі й функції в колективі, виявляти ініціативу, підтримувати та керувати власними взаєминами 3 іншими; впевненість у власних професійних можливостях; ініціативність; відповідальність; володіння навичками саморефлексії самоаналізу, саморегуляції, самооцінки і самоконтролю, самоактуалізації).

Відповідно до вимог сучасного суспільства вчитель сьогодні має бути не лише професійно компетентним і творчо активним, а й конкурентоспроможним фахівцем, характерними рисами якого $є$ високий рівень самостійності, гнучкість мислення, здатність до педагогічної рефлексії та сформована потреба в самовдосконаленні. Конкурентоспроможність педагога залежить від рівня розвитку його мотиваційної, пізнавальної та соціальної сфер, чому значною мірою сприяє ефективно організована внутрішньо шкільна методична робота [6, с. 42].

\title{
Лiтература
}

1. Буряк В. К. Педагогічна культура: теоретико-методологічний аспект / Володимир Костянтинович Буряк. - К. : Деміург, 2005. - 232 с. 2. Кондрашова Л. В. Высшая педагогическая школа и Болонский процесс: реалии и перспективы / Лидия Валентиновна Кондрашова. - Кривой Рог: КДПУ, 1996. - 74 с. 3. Левина М. М. Технологии профессионального педагогического образования: [учеб. пособ. для студ. высш. учеб. заведений] / Марина Михайловна Левина. - М. : Академия, 2001. - 272 с. 4. Малихін О. В. Організація самостійної навчальної діяльності студентів вищих педагогічних навчальних закладів: теоретико-методологічний аспект:[монографія]/ Олександр Володимирович Малихін. - Кривий Ріг: Видавничий дім, 2009. - 307 с. 5. Ничкало Н. Г. Розвиток професійної освіти і навчання в контексті Свропейської інтеграції / Н. Г. Ничкало// Педагогіка і психологія. - 2008. - № 1. - С. 57-69. 6. Митник О. Розвиток конкурентоспроможності сучасного вчителя у межах внутрішньошкільної методичної роботи / Олександр Митник // Рідна школа. - 2013. №1-2. - С. 37-42. 7. Рубинштейн С. Л. Основы общей психологии / Сергей Львович Рубинштейн. - СПб. : Питер, 2003. - 720 с.

$$
\text { УДК - 81'1: [378+004] }
$$

Ольга Захарчук-Дуке

\section{ЕЛЕКТРОННИЙ ПІРУЧНИК ЯК ОБ'ЄКТ ТЕОРЕТИЧНОГО АНАЛІЗУ В ЛІНГВІСТИЦІ ТА ЛІНГВОДИДАКТИЦІ ВИЩОЇ ШКОЛИ}

Захарчук-Дуке О. О. Електронний підручник як об'єкт теоретичного аналізу в лінгвістиці та лінгводидактиці вищої школи.

У статті проаналізовано різні формулювання поняття «електронний підручник», висвітлено переваги електронного підручника порівняно 3 лінійним, обгрунтовано доцільність роботи студентів з електронним підручником на заняттях у вищій школі в умовах Болонського процесу.

Ключові слова: Болонський процес, інформаційне суспільство, електронний підручник, гіпертекст, мультимедія.

Захарчук-Дуке О. О. Электронный учебник как объект теоретического анализа в лингвистике и лингводидактике высшей школы.

В статье проанализированы разные формулировки понятия «электронный учебник», описаны преимущества электронного учебника над линейным, обоснована целесообразность работы студентов с электронным учебником на занятиях в высшей школе в условиях Болонского процеса. 
Ключевые слова: Болонский процес, информационное общество, электронный учебник, гипертекст, мультимедия.

Zakharchuk-Dyuke O. O. The «electronic book» as an object of theoretical analyze in linguistics and lingvodidactic of higher school.

In the article were analyzed various defining terms of «electronic book», highlight the advantages of electronic book of linear, justified the relevance of work of students with electronic book classes at the school in High society in the Bologna process.

Key words: Bologna process, information society, electronic book, hypertext, multimedia.

Система вищої освіти за останні роки зазнала суттєвих змін, що пов'язано 3 упровадженням теоретичних засад Болонського процесу: використання інформаційнокомунікаційних технологій, ресурсів Інтернету, орієнтація вищої освіти на посилення зв’ язку змісту навчання з обраною професією, зростання значення самостійної роботи, індивідуалізації навчання студентів. Така переорієнтація освітнього процесу потребує нових підходів в організації навчання, нового погляду на підручники для вищої школи.

Meта статmі- проаналізувати різні визначення поняття «електронний підручник», окреслити модернізацію підручника в контексті інформаційного суспільства та у зв'язку з упровадженням вимог Болонського процесу.

Мета вищої освіти нині - це підготовка фахівців, здатних забезпечити перехід від індустріального до інформаційного суспільства через новаторство в навчанні та науково-методичній роботі [7].

Інформаційне суспільство - це суспільство, у якому виробництво і споживання інформації $є$ найважливішим видом діяльності; інформація визначається найбільш значущим ресурсом; нові інформаційні і телекомунікаційні технології і техніка стають базовими, а інформаційне середовище разом 3 екологічним і соціальним - новим середовищем людини [7].

Становлення інформаційного суспільства диктує необхідність модернізації класичної, традиційної освіти. Соціокультурна ситуація сьогодення веде до змін в освітніх технологіях [7].

Проблему визначення ефективної форми підручника в умовах інформатизації освіти, створення електронних підручників розглядали: С. Баликіна, К. Бугайчук, Г. Василенко, А. Вєлієва, В. Вуль, А. Гречихін, О. Гуркова, Е. Данильчук, І. Захарова, Е. Зайцева, А. Зеленцова, А. Земськов, С. Караман, А. Коджаспиров, Г. Коджаспирова, Е. Колесниченко, П. Коновалов, Н. Кононець, О. Лебедєв, В. Мадзігон, А. Родін, В. Хом'яков.

На думку науковців, стрімкий процес інформатизації і комп’ютеризації суспільства відкриває в освіті шлях електронним підручникам, що перебувають у полі зору багатьох науковців. Нині наявні різноманітні формулювання поняття «електронний підручник». Зокрема, такі:

- програмово-методичний комплекс, який забезпечує можливість самостійно чи 3 викладачем засвоювати навчальний курс, має можливість використовувати великий обсяг інформації, такої, як текст, графіка, мультиплікація, звук, анімація, відео, що дозволяє підвищити якість навчання за рахунок сприйняття інформації відразу кількома органами чуття паралельно, нове покоління підручників, призначених для самостійного вивчення предмета; може бути розміщений у мережі Інтернет, що збільшує його доступність у будь-який час, у будь-якому місці [4, с. 59]; 
- електронний варіант друкованих навчальних матеріалів, які мають позитивні властивості - компактність зберігання в пам'яті комп'ютера або на зовнішньому магнітному носії, можливість оперативного внесення змін і передачі на великі відстані електронною поштою, містить усі дидактичні, методичні, наукові та інформаційнодовідкові матеріали [9, с. 71];

- підручник, який занесено в комп'ютер, але організовано за принципом «гіпертексту» [5, с. 393];

- універсальний інтерактивний гіпермедійний методичний i дидактичний підручник, який містить широке коло питань 3 тем однієї дисципліни (або різних навчальних дисциплін), викладених у компактній формі гіпертекстового середовища, i призначений для використання в навчальному процесі [6, с. 202];

- педагогічні програмні засоби, які охоплюють значні за обсягом матеріалу розділи навчальних курсів або повністю навчальні курси. Для такого типу програмних засобів характерною є гіпертекстова структура навчального матеріалу, наявність систем керування $з$ елементами штучного інтелекту, модулів самоконтролю, розвинених мультимедійних складників [3];

- електронна навчальна система комплексного призначення, що забезпечує безперервність і повноту дидактичного циклу процесу навчання, дає можливість у діалоговому режимі, як правило, самостійно засвоїти навчальний курс або його розділ за допомогою комп'ютера i будується за модульним принципом із відкритою архітектурою [1, с. 67];

- навчальне електронне видання із систематизованим викладом дисципліни (iї розділу, частини), у якому рівнозначно і взаємопов'язано за допомогою відповідних програмних засобів подається текстова, звукова, графічна та інша інформація, що забезпечує безперервність і повноту дидактичного циклу процесу навчання, служить для групового, індивідуального або індивідуалізованого навчання, відповідає навчальній програмі й призначене для використання в навчальному процесі [2] тощо.

Незважаючи на різноманітність визначень, їх об'єднує те, що електронні підручники, по-перше, мають гіпертекст та мультимедіа, по-друге, служать для передачі великого обсягу інформації і, по-третє, зорієнтовані на самостійну роботу студента.

Електронний підручник, в основі якого лежить гіпертекст, має безумовну перевагу порівняно 3 лінійним текстом традиційного підручника. Наявність гіпертекстів дозволяє:

- швидко забезпечити доступ до об'єкта посилання і до його джерела;

- додавати нові посилання;

- уводити коментарі до тексту, не порушуючи його цілісність;

- автоматизувати процес формування ключових слів завдяки автоматичному аналізові тексту [10].

Гіпертекстовий підручник може застосовуватися в мережі Інтранет навчального закладу й у глобальній мережі Інтернет. Властивість відкритості електронних підручників порівняно 3 друкованими створює умови для необмеженого збільшення обсягу інформації.

Великі можливості відкриває використання мультимедіа (multi - багато, media середовище). Засоби мультимедіа передбачають застосування різноманітної інформації: комп'ютерні дані, теле- і відеоінформацію, звуковий і музичний супровід, що дозволяє підвищити якість навчання, подання та засвоєння великого обсягу інформації. За даними ЮНЕСКО, під час аудіосприйняття засвоюється тільки 12\% інформації, під час візуального - близько $25 \%$, а під час аудіовізуального - до $65 \%$ сприйманої інформації [10]. Отже, сприйняття інформації, під час якого задіяні кілька органів чуття, 
емоційно впливає на студента, сприяє засвоєнню нової, складної інформації у великому обсязі та логічній послідовності.

Сучасний підручник має звільняти студента від постійної необхідності нотувати лектора, надавати можливість повертатись до опрацьованого матеріалу задля повторення, спрямовувати самостійну позааудиторну роботу студентів, що особливо актуалізувалося $з$ упровадженням Болонського процесу. У навчальних планах чітко реалізується тенденція до скорочення аудиторних годин та збільшення годин для самостійної роботи студента (50-60 \% навчального часу). Через скорочення аудиторних годин можливе компенсування часу за умови вмілого впровадження в навчальний процес електронного підручника, яким передбачено:

- самостійну пізнавальну діяльність;

- роботу студента з інформацією в тій формі, послідовності, темпі, які імпонують саме йому;

- різноманітну послідовність вивчення навчального матеріалу;

- індивідуальне вивчення матеріалу, що сприяє розв’язанню проблему індивідуалізації навчання.

Використання комп'ютерних технологій у навчанні загалом та електронних підручників у навчальному процесі зокрема зумовлює зміну ролі викладача: від функції накопичувача та розповсюджувача наукової інформації до ролі тьютора, який об'єднує три функції - викладача, консультанта та менеджера освітнього процесу [7].

Провідний спеціаліст ЮНЕСКО Раджа Рай Сингх зазначає, що у процесі освіти ми вчились у минулого, намагаючись відтворити і відновити його; настав час учитися в майбутнього, випереджаючи його [8]. Звичайно, повністю відмовитись від традиційних підручників неможливо, оскільки нічим не замінити живого спілкування, за допомогою якого викладач мотивує, зацікавлює студентів. Однак не можна недооцінювати значення інформатизації суспільства загалом та інформатизацію навчання зокрема, оскільки застосування сучасних технологій - це можливість усунути суперечність між освітою і вимогами життя.

\section{Література}

1. Балыкина Е. Н. Подходы к проектированию компьютерных тестов учебных достижений по историческим дисциплинам [Текст] / Е. Н. Балыкина // Информационное обеспечение исторического образования: сб. ст.; под. ред. В. Н. Сидорцова, А. Н. Нечухрина, Е. Н. Балыкиной. - Вып. 3. - Мн. - Гродно, 2003. - С. 67-75. 2. Бугайчук К. Л. Інформаційні технології і засоби навчання. 2011. №2 (22). 3. Вєлієва А. Ш. Електронний підручник: можливості та перспективи [Електронний peсурс] / А. Ш. Вєлиєва, Е. Р. Сулеманова // Материалы V Международной научнопрактической конференции «Наука в информационном пространстве» (30-31 октября 2009 г.). 4. Данильчук Е. В. Електронный учебник: новое качество обучения // Современный вузовский учебник: проблемы и решения : сборник материалов межвузовского «круглого стола» 19 декабря 2000г. - Волгоград, 2001г. - (С. 59-62); 5. Коджаспирова Г. М. Словарь по педагогике / Г. М. Коджаспирова, А. Ю. Коджаспиров. М. : ИКЦ «МарТ»; Ростов н/Д: Издательский центр «МарТ», 2005. - 448 с. 6. Кононець Н. В. Аспекти педагогічної майстерності викладача: розробка електронних підручників / Н. В. Кононець // Витоки педагогічної майстерності : зб. наук. праць. 2009. - № 6. 7. Кремень В. Г. Вища освіта України і Болонський процес: навч. посіб. / За ред. В. Г. Кременя. Авторський колектив: М.Ф. Степко, Я. Я. Болюбаш, В. Д. Шинкарук, В. В. Грубінко, І. І. Бабин. - Тернопіль: Навчальна книга - Богдан, 2004. - 384 с. 8. Раджа Рай Сингх. Образование в условиях миняющегося мира// Перспективы. Вопроссы образования. 1993. №1. 9. Родин А. Ф. Электронный вузовский 
учебник: плюсы и минусы // Современный вузовский учебник: проблемы и решения : сборник материалов межвузовского «круглого стола» 19 декабря 2000 г. - Волгоград, 2001. - С. 71-73. 10. Точиліна Т. М. Науково-теоретичні засади створення навчальнометодичного комплексу з курсу загальної фізики для вищих технічних навчальних закладів / Т. М. Точиліна. - К., 2006. - 220 с.

УДК 371.134:821.161.2

Свімлана Кампов

\section{КОМПЕТЕНТНІСТЬ І САМОСТІЙНІСТЬ У СИСТЕМІ ПІДГОТОВКИ МАЙБУТНЬОГО ВЧИТЕЛЯ}

Кампов С. П. Компетентність і самостійність у системі підготовки майбутнього вчителя.

У статті з'ясовується сутність педагогічної категорії на основі осмислення, узагальнення й систематизації поглядів сучасних науковців. Подається спроба генезису поняття у психолого-педагогічній літературі. 3'ясовано, що компетентність $\epsilon$ сукупністю властивостей особистості, які забезпечують ефективне, раціональне і творче використання знань i вмінь самостійного розв'язання завдань в умовах професійних ситуацій та інтересах освітнього закладу.

Ключові слова: компетентність, професійна самостійність, учитель, педагогічна освіта, навичка, уміння.

Кампов С. П. Компетентность и самостоятельность в системе подготовки будущего учителя.

В статье на основе систематизации и обобщения научных взглядов известных исследователей сформулировано понятие «компетентность», охарактеризована его сущность в сфере профессиональной подготовки будущих учителей, рассмотрена эволюция внедрения этого понятия в научный аппарат педагогической отрасли. Установлено, что компетентность - это система свойств личности, которые обеспечивают эффективное, рациональное и творческое использование знаний, умений, навыков для самостоятельного решения задач в условиях профессиональных ситуаций и удовлетворения интересов образовательного учреждения.

Ключевые слова: компетентность, профессиональная самостоятельность, учитель, педагогическое образование, умение, навык.

Kampov S. P. Competence and independence in the training of future teachers.

The article reveals the essence of educational category based on comprehension, generalization and systematization of modern scientists' views. The article points the attempt of the concept genesis in the psycho-pedagogical literature. The author stated that the competence is a system of personality traits. These traits provide an effective, efficient and creative usage of knowledge and skills that help to solve the problems independently in professional situations and interests of the educational institution.

Key words: competence, professional independence, teacher, pedagogical education, skills, abilities.

Як засвідчує досвід, зміст сучасної освіти лише частково відповідає запитам сучасного демократичного суспільства України, а відтак, не спрямований на набуття особистостями необхідних знань i умінь для їх повноцінного існування в соціокультурних умовах XXI століття. Одним із ефективних шляхів оновлення змісту 